\title{
CHINA AS A CAPITALIST STATE: FROM 'PRIMITIVE SOCIALIST ACCUMULATION" TO NEOLIBERAL CAPITALISM
}

EDDIE J. GIRDNER

\begin{abstract}
This paper will briefly explore the trajectory of Chinese development from 1948 to the present. It will argue that the Maoist period laid the basis for industrial development under an essentially import substitution industrialization pattern of development and essentially state-led capitalist accumulation, while liberalization and the opening to world markets, beginning with Deng Xiaoping in the 1970s, has culminated in the consolidation of a neoliberal pattern of capitalist accumulation today.

China has undergone two profound transformations since 1948. In spite of the setbacks during the "Great Leap Forward" and the lost development opportunities during the Cultural Revolution, the Maoist period mobilized the resources of the country for rapid development.

Chinese development is part and parcel of the neoliberal capitalist development all across the developing world. China, since the Revolution in 1948, has emerged from a country engaged in primitive "socialist" accumulation under Mao to accumulation under the current global wave of neoliberalism orchestrated by the IMF and World Bank.
\end{abstract}

\section{KEYWORDS}

China, Capital Accumulation, Neoliberalism, China and Global Economy, Economic development in China. 


\section{Introduction}

This paper will briefly explore the trajectory of Chinese development from 1948 to the present. It will argue that the Maoist period laid the basis for industrial development under an essentially import substitution industrialization pattern of development and essentially state-led capitalist accumulation, while liberalization and the opening to world markets, beginning with Deng Xiaoping in the 1970s, has culminated in the consolidation of a neoliberal pattern of capitalist accumulation today.

China has undergone two profound transformations since 1948. In spite of the setbacks during the "Great Leap Forward" and the lost development opportunities during the Cultural Revolution, the Maoist period mobilized the resources of the country for rapid development. The foundation was laid for the emergence of China as a major player in the global political economy with the reforms of Deng Xiaoping. Fifty years of development saw a phenomenal sustained growth rate of some 10 percent for the entire period. ${ }^{1}$ From 1978 to 1992 , the growth rate was the highest in the world, at nine percent per year. ${ }^{2}$ Since 1978, the "Iron Rice Bowl" has been largely dismantled, and the economy opened to transform China into a fully capitalist society under the agenda of Deng Xiaoping and his successors. The authoritarian political structure has been kept in place $^{3}$, while there has been a significant degree of economic and political decentralization.

Deng emphasized "getting wealthy." For China, in his view, it was necessary to "use capitalism to build socialism." This meant encouraging the emergence of a Chinese bourgeoisie, letting some get rich first. In fact, it would be a regimen of capitalist accumulation, mostly in private hands, that would provide the engine of growth for

${ }^{1}$ Maurice Meisner, "China's Communist Revolution: A Half-Century Perspective," Current History, Vol. 98 (629) September 1999, p. 245.

${ }^{2}$ Alka Acharya, "Two Eras and After: People's Republic of China at 50," Economic and Political Weekly (Hereafter EPW), Vol. 34 (41) October 9, 1999, p. 2906.

3David S.G. Goodman, "Introduction: The Authoritarian Outlook," in David S.G. Goodman and Gerald Segal, (eds.) China in the Nineties, Oxford Clarendon Press, 1991, pp. 1-18. 
China's entry into the global capitalist system. Neoliberal capitalist accumulation in China has proceeded in various ways, ${ }^{4}$ for example by turning over state assets and factories in townships and villages to private hands. Today practically all essential elements of the Chinese economy operate on a capitalist basis. With the emergence of capitalist enterprises, inequality has greatly increased, along with the other ills typically associated with capitalist development in relatively high-growth areas of the emerging third world. Among these are environmental degradation, unemployment, corruption and increasing inequality. ${ }^{5}$ By 1997, 45 percent of respondents in a survey of urban households had experienced a decline in income. The top 1.3 percent of urban households owned assets over 200,000 yuan each, which was 31.5 percent total assets, while the bottom 44 percent of households owned only three percent of all assets. ${ }^{6}$

Indeed one can make many meaningful comparisons between China and development in other countries across the developing world, as countries moved from the era of import substitution industrialization to neoliberalism. Today development in China is, in significant ways, a part with the prevailing neoliberal agenda, regardless of the legitimizing underlying political rhetoric. ${ }^{7}$ While wholesale capitalization of the economy has gone forward, Deng Xiaoping and his successors, such as former President Jiang Zemin ${ }^{8}$, and his successor President Hu Jintao, have kept a tight political lid on the country. All across the developing world people have lost what guarantees existed to secure employment, health care, education and broader social welfare. States have been dismantled to end "rent seeking." Rolling back the state and implementing "structural adjustment" requires strong states and generally precludes meaningful

\footnotetext{
${ }^{4}$ Xiaobo Hu, "The State, Enterprises, and Society in Post-Deng China," Asian Survey, Vol. 40 (4) July-Aug. 2000, pp. 644-5; Marc Blecher, "Sounds of Silence and Distant Thunder: The Crises of Economic and Political Administration," in Goodman and Segal, (eds.), pp. 25-63.

${ }^{5}$ Nirmal Kumar Chandra, "FDI and Domestic Economy: Neoliberalism in China," EPW, Vol. 34 (45), November 6, 1999, pp. 3209-10.

${ }^{6}$ Ibid., p. 3210.

${ }^{7}$ Ibid., pp. 3195-3212.

${ }^{8}$ Bruce Gilley, "Jiang Zemin: On the Right Side of History?" Current History Vol. 98 (629), pp. 249-53.
} 
democracy. While corruption and bloated bureaucracies are realities that must be addressed, neoliberalism seeks to relegate politics to the sidelines.

It is useful to explore the emerging political economy of China in the context of fifty years of the Revolution, on the one hand, and the nationalist agenda of China today as it emerges as a major global player, on the other. The Maoist period went far in eliminating the worst feudal excesses of the countryside and bringing about necessary modernization, but Deng understood that to complete the process of "development" China would have to become a powerful player in the global economy. ${ }^{2}$ The model of successful state-led capitalist development was already in place in Japan, South Korea, Taiwan, and Singapore. ${ }^{10}$ These largely authoritarian, statist, and state-led capitalist nations also had a history of land reform and extensive rural development ${ }^{11}$. Today emerging countries under the current global agenda of neoliberalism are forced to follow an authoritarian neoliberal agenda if they wish to enrich themselves, enter the consumer revolution, have high rates of growth and become powerful players on the world stage. They may utilize the ideological and often nationalistic rhetoric of the founding fathers, in this case Marx, Lenin, and Mao, as a legitimizing function ${ }^{12}$, but they must nevertheless pursue neoliberal capitalism to attract capital and build large state-guaranteed firms to capture large shares of the global market in areas such as electronics and communications. It is the successful East-Asian development model which we see in place in China today.

\footnotetext{
${ }^{9}$ Goodman, pp. 2-5.

${ }^{10}$ Gilley, pp. 249-53.

${ }^{11}$ Richard Grabowski, "Development States and Rural Development," Scandinavian Journal of Development Alternatives and Area Studies, Vol.19 (4), December 2000, pp. 24-25.

${ }^{12}$ David Kelly, "Chinese Marxism Since Tiananmen: Between Evaporation and Dismemberment," in Goodman and Segal, (eds.), pp. 19-34. As Evans has noted concerning Deng, "Far from seeing political liberalization as a necessary condition for economic liberalization, he has seen it as a serious potential threat to social and political stability and therefore to development." Richard Evans, Deng Xiaoping and the Making of Modern China, London; Hamish Hamilton, 1993, p. 219.
} 
Under Mao, China pursued a considerable degree of equality and social welfare, which raised the level of human capital. For Mao, a socialist train that ran late was better than a capitalist train that ran on time. ${ }^{13}$ For Deng, on the other hand, accumulation and modernization, was "Moses and the prophets," and this could not be carried out under Maoist egalitarianism. When Deng finally prevailed against his enemies and took the helm in 1977, he stressed a decline in social order, crime, industrial absenteeism, gangsterism on the railways, increasing levels of urban unemployment, abuse of the people by local party officials, and increasing cynicism among the peasants and workers. ${ }^{14}$ The Mao era had run out of steam and Deng launched the famous cat theory. "It doesn't matter if the cat is white or black as long as it catches the mice," "A few have to get rich first," and "To get rich is glorious." All these mantras apply essentially to capitalist accumulation. The other side of the coin, however, was that to greatly accelerate capitalist accumulation, a great deal more inequality would have to be created. Greater social turmoil and tensions would emerge. The emerging bourgeoisie would eventually demand a "democratic" voice. Billions of dollars of foreign direct investment (FDI) capital from abroad would be mobilized for this transformation in addition to local accumulation. The results were quite predictable. Great economic progress has been achieved, from the Dungist era, while the spectrum of ills associated with rapid development under neoliberalism seen elsewhere in the developing world have flourished.

In 2001 the Communist Party of China was at pains to present essentially capitalist views of accumulation as Marxist-Maoist orthodoxy while dealing with the emerging leftist critique and the rise of a genuine proletariat at odds with the capitalist pattern of ownership of the means of production. ${ }^{15}$ State leaders and their families busied themselves getting rich ("gloriously") from the surplus produced by the emerging Chinese industrial proletariat.

\footnotetext{
${ }^{13}$ Ibid., p. 143.

${ }^{14}$ Evans, p. 223.

${ }^{15}$ Feng Chen, "An Unfinished Battle in China: The Leftist Criticism of the Reform and the Third Thought Emancipation," The China Quarterly, No. 158, June 1999, pp. 447-67.
} 
As a "big emerging market," China is on the way to becoming a modern country and significant player in the global economy. China is the second largest industrial producer in the world and third largest in GDP in purchasing power parity, after the US and Japan. China may become the world's largest economy by 2015 . The government target is a GDP of $\$ 1.5$ trillion by $2005 .^{16}$

\section{China as a Nationalist Developmentalist State}

China's development throughout both the Maoist and Dengist periods of transformation has been capitalist in essence, rather than socialist. ${ }^{17}$ The Maoist period of primitive accumulation laid the basis, in terms of material and human capital, for the transition to neoliberal capitalism in the 1990s and integration into the global economy. Viewed from this perspective, Chinese development during the latter half of the twentieth century was only a variation of the type of import substitution industrialization seen elsewhere in the developing world. It was nationalist and statist developmentalist. Under state control accumulation was more rapid that in India, and with greater equality, it was possible to make greater inroads into the crucial need to raise the level of human capital. Under Deng, on the other hand, China accelerated structural adjustments, dismantled the Iron Rice Bowl, accelerated the high rate of growth and greatly increased material production and consumption, while at the same time greatly increasing inequality, unemployment and the other ills of rapid accumulation. It is only today that a modern industrial proletariat with leftist tendencies and oriented to class struggle can emerge, in class-struggle against global capital and the extraction of excess surplus value under Dengist neoliberal reforms. ${ }^{18}$

\footnotetext{
${ }^{16}$ Meisner, p. 247.

${ }^{17}$ Ibid., pp. 243-48.

${ }^{18}$ Acharya, pp. 2907-8; Wang Hui, "Fire at the Castle Gate," New Left Review, Vol. 6, Nov-Dec. 2000, pp. 69-99; Samir Amin, "The Political Economy of the Twentieth Century," Monthly Review, Vol. 52 (2), June 2000, pp. 1-17.
} 


\section{The Revolution and Maoist Era}

In China, under the Theory of New Democracy, the "bourgeois phase" of capitalism was to be carried out by the four classes: workers, peasants, the national bourgeoisie, and the petty bourgeoisie. ${ }^{19}$ The Maoist period carried out the building of a modern state seen in national unity, national independence, an effective central government, revival of the cities, the elimination of the feudal traditional ruling class in the countryside, improving human capital, establishing education and providing basic health care. ${ }^{20}$

The industrial basis for development was laid rapidly under Mao with the population gaining in absolute material wealth and well-being with improvements in diet, welfare, health care and education. Life expectancy doubled from only 35 years in 1949 to 65 years in $1976 .{ }^{21}$ Public education and social security contributed significantly to the sustained growth which emerged in Deng era.

Mao's economic development policies, essentially what Leon Trotsky called "primitive socialist accumulation," were, contrary to conventional wisdom, highly successful. The village population was exploited for the accumulation of capital. In the first 25 years, on average, industrial growth was at 10 percent, agriculture at 4 percent, grain output at 3.7 percent and overall growth at 6.5 percent. $^{22}$

\section{Chinese Development under Deng Xiaoping}

The Third Plenary Session of the Eleventh Central Committee of the Communist Party of China in December 1978 led to immense changes that would result in the insertion of China into the global political economy. Deng encouraged direct foreign investment of capital, the borrowing of capitalist techniques, and implementing the

\footnotetext{
${ }^{19}$ Meisner, p. 244.

${ }^{20}$ Ibid., pp. 244-5.

${ }^{21}$ Ibid., p. 246.

${ }^{22}$ Acharya, p. 2906.
} 
"four modernizations:" agriculture, industry, the military and science and technology.

Deng attempted to square this apparent departure from China as a "socialist country" by arguing that the material productive realm could be separated from the political or ideological realm. As long as the Party remained "socialist," then China would be a socialist country.

Deng's reforms enabled China to begin the transition from the "easy phase" of development to export orientation and competition in the global market. The Chinese economy had reached a "plateau" in the early 1970s; foreign direct investment (FDI) and technology were needed to ready China for global competition. The opening up of the economy, Deng's own brand of structural adjustment program, the dismantling of the Iron Rice bowl of social welfare, and privatization were, in fact, typical of the East Asian state-development model seen elsewhere. While Deng spoke of "market reforms with Chinese Characteristics," and "socialism as an ideology of modernization," 23 he was simply bringing China into the era of neoliberal capital accumulation.

Being not only a "capitalist roader," but having a neoliberal mentality as well, Dung would not hesitate to use authoritarian methods to avoid disruptions such as the Great Proletarian Cultural Revolution which he bitterly criticized. ${ }^{24}$ In turning the economy over to a technocratic and bureaucratic capitalist elite, ... "the distinction between capitalism and socialism would be blurred beyond recognition." 25 In Dung's China the economy would be based on wage labor; China would be integrated into the world capitalist economy; profit making would be the main goal of economic life; labor would be fully commodified; the Iron Rice Bowl would be smashed; there would be a surplus army of labor of some 200 million; and the major emphasis would be on entrepreneurship and the emergence of a new bourgeoisie. ${ }^{26}$ In this profile, the economy is

\footnotetext{
${ }^{23}$ Ibid., pp. 2906-7.

${ }^{24}$ Acharya, pp. 2907; Evans, pp. 164-65.

${ }^{25}$ Evans, pp. 164-65.

${ }^{26}$ Meisner, p. 247.
} 
little different than in other "big emerging market" countries today, the main difference being that the Chinese are more "gung-ho." A wide and growing disparity in development emerged rapidly between different regions of the country. A flourishing market economy emerged $^{27}$ with success today is measured in the high rate of savings and investments, higher rates of literacy, higher life expectancy, (officially) the lowest number under the poverty line in the developing world, and the use of human capital to create an extensive infrastructure. ${ }^{28}$

Capitalism under Deng and his successors has led to greater authoritarianism, political repression, labor exploitation under transnational capital, repatriation of profits abroad, a resurgence of feudalistic practices in the countryside, a lack of emphasis on education, and the rise of unrest as seen in the Tiananmen Square incident in 1989. Indeed, the roots of future working class solidarity may well trace its roots to Tiananmen. ${ }^{29}$ As one observer has noted, "It would be one of the great ironies of modern Chinese history if the capitalist development set in motion by the Communist state produced a proletariat class that embarks on a democratic and socialist struggle against a ruling Communist Party ritualistically claiming to represent the working classes." 30

\section{Tiananmen: The Triumph of Neoliberalism}

The Tiananmen protest was not a revolt against communist brutality, as claimed by the western media, but rather a reaction to Deng's state-led capitalist reforms. ${ }^{31}$ The defeat of the students and

${ }^{27}$ Chandra, p. 3211; Blecher, p. 48; Margot Schueller, "Liaoning: Struggling with the burdens of the past," in David S.G. Goodman, (ed.) China's Provinces in Reform: Class, Community and Political Culture, London, Routledge, 1997, p. 94.

${ }^{28}$ Acharya, p. 2906.

${ }^{29}$ Acharya, p. 2906-08; Robert Weil, Red Cat, White Cat, New York, Monthly Review Press, 1996, pp. 250-51. William Hinton, The Great Reversal, New York, Monthly Review Press, 1990, pp. 188-89.

${ }^{30}$ Meisner, p. 248.

${ }^{31}$ Goodman, p. 11. 
workers at Tiananmen marked the triumph of neoliberal capitalism in China. ${ }^{32}$ The Tiananmen protest arose as a movement demanding the freedom to debate political and economic issues in China, but participants were also expressing their grievances against Deng: the working class had expected an increase in their living standards in the 1980s, but this was not fulfilled ${ }^{33}$; the Iron Rice Bowl of social welfare guarantees had been broken; there was high inflation; workers were being squeezed with capitalist-style speed-ups in the factories and penalized for shoddy work; there were large layoffs due to contracting out, streamlining, and privatization; jobs were threatened and unemployment was rising with a large floating population of millions in the cities ${ }^{34}$; mental labor was seen as more valuable than manual labor; there was no alternative vision of socialism and no institutions whereby the working class could defend their rights; ${ }^{35}$ workers were confused as they were told that they were part of a worker's state, yet were highly exploited. Before the Tiananmen Uprising, workers were hesitant to protest against the state; now increasing resentment led to the slogan: "The Workers are no Longer Silent." 36

Peasants too were increasingly unhappy with Deng's reforms. After initially benefiting from the disbanding of the communes, they were caught in a price squeeze with cost of inputs increasing faster than the commodities they produced. A fertilizer shortage resulted in protests in the countryside. Further "Laissez Faire Socialism" increased unease about some growing rich, while others did not, with the lucky ones upheld as model individuals by the Party. Many had gotten rich because they were officials, or sons and daughters, of officials. Corruption had increased. Entrepreneurs had bought items from the state at low prices and sold them for several times what they paid on the open market. This rising inequality caused jealousy between those whose incomes had stagnated in the public sector and

32“A Dialogue on the Future of China," New Left Review, No: 235, May/June 1999, pp. 62-106.

${ }^{33}$ Goodman, p. 15.

${ }^{34}$ Anita Chan, "The Social Origins and Consequences of the Tiananmen Crises," in Goodman and Segal, (eds.), pp. 108-112, 121-122.

35 "A Dialogue on the Future of China," p. 63.

${ }^{36}$ Chan, pp. 108-111, 124. 
those in the private sectors, such as some peasants who benefited initially from the free market and became "rich." Along with rising inequality, privatization led to the collapse of the health care system and large medical bills. Some primary schools were closed for lack of funds. Children from the rich families were admitted to universities without passing the entrance examinations as long as they paid a higher fee. ${ }^{37}$

Corrupt officials began using their networks and connections to enjoy a lavish life style and enrich themselves, ${ }^{38}$ importing expensive cars. ${ }^{39}$ Officials, including Deng Xiaoping, set their children and relatives up to control lucrative sectors of the economy bringing crony capitalism under the guise of socialism; indeed these practices were seen as an elements of the new "socialism." Students demanded that officials and their children make public their assets and bank accounts known and that $\mathrm{Li}$ Peng and Deng resign. ${ }^{40}$

While "rapid social change" had taken place in the 1980s within a "rigid political structure" and Government policies were still promoted as "socialist," there was no institutional framework to provide an outlet for people's grievances. Authority continued to be vested in a few key individuals, rather than in institutions. The demand arose among those in the "People's University" for an opposition party, modeled on Poland's Solidarity. It was argued that the Chinese Communist Party could no longer represent the people. As a liberalizer, General Secretary Zhao Ziyang, favored the western democratic model of pressure groups, but was relatively weak and unable to put these demands into practice due to the staunch opposition of Deng and Premier Li Peng. The conservatives feared loss of control over the Party to the liberals. ${ }^{41}$

\footnotetext{
${ }^{37}$ Ibid., pp. 106-120.

${ }^{38}$ Ibid., p. 115.

${ }^{39}$ Lawrence R. Sullivan, "The Chinese Communist Party and the Beijing Massacre: The Crises in Authority," in Goodman and Segal (eds.), pp. 9091.

${ }^{40}$ Chan, p. 125.

${ }^{41}$ Sullivan, pp. 87-94.
} 
There were indeed sharp divisions among intellectuals, with the main stream expressing a belief in "free market capitalism," but broadly demanding greater political representation in politics. ${ }^{42}$ Intellectuals were unhappy with the dogmatic anti-intellectualism in the Party and viewed the Conservative Chinese Communist Party (CCP) officials as "narrow minded," "stupid," and "peasant-like." 43 At the same time, many of these intellectuals distanced themselves from the struggles of the workers.

Students at Tiananmen called for more democracy including: the institutionalization of a more pluralistic decision-making system, the right of dissent from the political leadership, the right to speak out, the right to demonstrate, an independent press, the recognition of student associations independent of the Government, and an independent judicial system. These were demands for freedom from the restrictions and humiliations continuously imposed by bureaucrats. ${ }^{44}$

The students argued that Deng's policies jeopardized China's future but when they asked for a dialogue and more democratic rights, Premier Li Peng imposed martial law. While diverse in their thinking, the students were generally a progressive coalition, neither far right not left. The right wing "reactionaries" consisted of Deng and his group. ${ }^{45}$ While General Secretary Zhao Ziyang, on the left wing, was willing to promote a degree of political liberalization he was being pressured by the right wingers to resign and subsequently fired by Premier Li Peng.

Government reform, not overthrow was the objective of the students. Instead, Deng launched a brutal massacre to "teach the students a lesson." 46 Several thousand, including workers, were killed at Tiananmen. It was the participation of the workers, the broad masses, in fact, that was the most disturbing to the elite, rather than the demands of the students, termed "bourgeois liberal intellectuals"

\footnotetext{
42"A Dialogue on the Future of China," pp. 63-64.

${ }^{43}$ Sullivan, p. 93.

${ }^{44}$ Chan, pp. 125-6.

${ }^{45}$ Hinton, The Great Reversal, p. 190; Sullivan, pp. 88-90.

${ }^{46}$ Sullivan, pp. 180-184.
} 
by the Government to discredit them. While the movement enjoyed broad support among the people, the solidarity between the students and the workers was weak. This was because many students on the right wanted faster economic reforms. Communist Party leader Yang Xianyi called Deng's crack down a "fascist coup." For William Hinton, Deng's betrayal of the revolution had turned the country into an absolute military dictatorship and proved Mao right that the "capitalist roaders" would bring a "fascist regime if they came to power. Deng and Premier Li Peng's massacre at Tiananmen marked the triumph of neoliberal capitalism in China, proved to the world that China was not "socialist" (if observers could have understood the political dynamics), and guaranteed the rise of an opposition worker's proletariat. ${ }^{47}$

\section{The Rising Bourgeoisie, Inequality, and Economic Contradictions}

The emerging entrepreneurial class in China includes those who became rich through opening restaurants and shops and operating expanding village and township industries. Most of these individuals came from more downscale backgrounds. A second group is made up of corrupt officials and their children, a phenomenon which emerged in the 1980s. Many of these were able to take advantage of a two-track pricing system to buy state goods cheaply and sell them for several times more on the open market. Most notable here are the three sons in law of the late Deng Xiaoping. In 1999 , these three individuals held pivotal positions in the economy in the areas of weapons procurement, the gold trade, and the rapidly emerging field of high technology. Many involved were able to go into private business after quitting their official government posts. The family of Yang Shangkun, who was head of the Army, was involved in the pattern of government officials taking over huge chunks of industry, amassing private fortunes and making deals with foreign capitalists. The Palace Hotel in Beijing was owned at the time

${ }^{47}$ Hinton, pp. 186-187; Chan, pp. 125-129; "A Dialogue on the Future of China," p. 64. Wang Hui, "Fire at the Castle Gate," New Left Review, 6 Nov. Dec. 2000, pp. 69-99. 
by the Army and a group from Manila. ${ }^{48}$ Money was often stashed in Swiss bank accounts.

It is notable that China went from being one of the most egalitarian nations to one of the most inegalitarian in the short two decades since Deng Xiaoping's policies were launched. No one can take issue with the fact that the rate of economic growth has been impressive, but researchers note a number of rising disparities between the urban and rural, the coast and inland, joint ventures and state-owned enterprises. Fully one-third of the private savings in the country are held by only 0.1 percent of the population. While the real rate of unemployment is unknown, there is a massive floating population in the large cities, especially in coastal areas. Economist $\mathrm{Hu}$ Angang has cited a figure of from 8 to 8.5 percent as the urban unemployment rate (16.4 million people) while the official government figure is 3.1 percent. What is acknowledged across the board is that unemployment is the highest since the founding of the PRC in $1949 .{ }^{49}$ Further recent estimates from Hu Angang consider the real rate of urban unemployment to be $8-9$ percent with 13- 15 percent unemployment in the old industrial area of Northeast China.

Among the reforms in 1990 which have increased these patterns are the privatization of agriculture, privatization of industry, and decentralization, which led the coastal areas to bid against the interior for resources as they made large profits. Some have argued that these developments brought the country close to economic chaos, ${ }^{50}$ even while economic growth figures remain high.

Other problems with the new economy have included a shortage of supplies in critical areas; power cuts which forced factories to work two to three days a week instead of six; some prices soaring out of control; massive corruption, with the moral degradation of the old society returning; prostitution, and begging along with mutilation of children for the purpose of begging; increase in the huge pool of unemployed, with some 50 million uprooted from

${ }^{48} \mathrm{Li}$ Cheng, “China in 1999," Asian Survey, Vol. 40 (1) Jan-Feb. 2000, p. 117-118; Hinton, pp. 187-88.

${ }^{49} \mathrm{Li}$ Cheng, p. 121.

50Hinton, p. 188. 
the countryside in one winter alone. The government was forced to shut down some 10,000 construction projects to combat inflation which in itself created some four to five million additional unemployed. $^{51}$ In the summer of 2004, some 6000 industrial enterprises in Shanghai were forced to shift to operating from midnight to eight AM because of power shortages.

Other aspects of recent change include a virtual collapse of birth control and family planning and a crisis in education in the countryside. Appeals have been made to the rich for donations through the "Hope Project" to which some wealthy industrialists like "self made billionaire," Li Xiaohua have donated. Low pay for teachers has led to instructors and professors being forced to use their time off selling ice cream and other items or moonlighting on second and third jobs to make ends meet. Health care is being privatized, leading to and a decay of normal services and standards. ${ }^{52}$ Some schools have been turned into virtual factories making such items as fireworks, as they have to provide their own funding. Housing is increasingly being privatized.

\section{The Emergence of the Leftist Critique}

A significant feature of full fledged capitalism in the People's Republic is the emergence of a genuine left opposition to statesponsored and state underwritten capitalism. It is clear that this is causing major headaches to the Government and Deng once ordered a halt to all debates on "isms" in the early 1990s. Nevertheless, a "new left" is emerging. With the economic model based on the emergence of Japan, South Korea, and Taiwan, and with the state providing the financing to create large multinational conglomerates as the backbone of the nation's industry ${ }^{53}$, intensified exploitation of the working

\footnotetext{
${ }^{51}$ Ibid., pp. 188-89.

${ }^{52} \mathrm{Li}$ Cheng, pp. 112-114; Hinton, p. 189.

${ }^{53}$ Biswatosh Saha, "Emerging MNC's from China: A Case Study," $E P W$, Vol. 35 (48) Nov. 25-Dec. 1, 2000, pp. 4234-45. See also Alka Acharya, "Li Peng's India Visit: Ritual and Reality," EPW, Vol. 36 (5 \& 6), Feb. 310, 2001, pp. 437-39. DN, "Basis of China's Competitiveness," $E P W$, Vol. 36 (7), Feb. 17, 2001, pp. 524-25.
} 
class provides an easy target for a leftist critique based on Marxist analysis. On the other hand, the ruling elites still claim Marxism as the official ideology.

Mao Zedong predicted that if Deng and his gang ever came to power and destroyed the revolution, the people would rise up and bring revolution again. ${ }^{54}$ Emerging left groups seek to join with workers and peasants, struggling for the benefits they enjoyed under the Iron Rice Bowl and against the emerging capitalist economy that imposes a price squeeze in the countryside and robs peasants of the fruits of their labor.

Works of new thinkers on the left, known as wanyanshu $(10,000$ word articles), have emerged as the debate continues. Economic polarization, rampant corruption and structural dislocation is giving fertile soil to the emergence of this left opposition to the current regime. The ruling class attempt to portray the actually existing regime as "socialist" is shown to be completely bankrupt by these critics. In the official ideology, following Deng, whatever is good for productivity is "socialism" 55 and ownership of shares of stock in companies is dubbed as "social ownership."

One typical left treatise argues that the "reforms" have threatened China's national security and are destabilizing the political system. Crucial here is the changing nature of the structure of ownership, class relations, social consciousness, and the state of the ruling party. Assets transferred from the state have become a source of primitive capitalist accumulation for a newly emerging bourgeoisie and class polarization is occurring with the emerging demand from new owners of the means of production for a political voice through representation. This new bourgeoisie has been able to make some inroads into entering the political system through local village elections. The rise of materialism, hedonism and money worship is

\footnotetext{
${ }^{54}$ Hinton, pp. 189-90.

${ }^{55}$ Feng Chen, “An Unfinished Battle,” p. 449.
} 
rampant; on the other hand, party organizations at the grass-roots level have deteriorated. ${ }^{56}$

Another leftist writer argues that the high rate of growth experienced subsequent to 1978 was not due to Deng's reforms. Growth in the 1977-78 period was around 14 resulted primarily from special government policies given to emerging private or semi-private enterprises and to illegal activities that have led to rapid privatization. Shareholding in profit-making companies cannot be public ownership; this assertion distorts Marxism beyond recognition. ${ }^{57}$

For leftist writers, the type of reforms carried out in the USSR and Eastern Europe, forwarded under the logic of "economic man," inevitably lead to capitalism. This logic has been seen in the breaking of the Iron Rice Bowl in China which undermined socialism. State Owned Enterprises (SOEs) brought great economic growth in the Maoist era; capitalism is being restored; but it is not too late to reverse the trend in the view of those who wish to engage in struggle. This is a political platform of the left. He Xin attacks "western ideas" as hostile, destabilizing and subversive. ${ }^{58}$

Efforts by the CCP to counter these forceful arguments of the left actually fare rather badly. Some speak of an "ideological crisis" for the Party. Am attempt to defend Government policy as "socialist" was launched by Xin Bengsi, who utilized the concept of "New Socialism" claiming that new socialism emphasizes the economy, while traditional socialism emphasized politics. Xin Bengsi lists five goals of the market economy: diversifying the forms of public ownership; reducing the scope of the state economy; supporting nonstate sectors; price, tax, and financial policies which favor the private sector; and the common prosperity of society. ${ }^{59}$ It is preposterous, of course, to see anything "socialist" here; these are merely some IMF structural adjustment guidelines used all across the developing world

\footnotetext{
${ }^{56}$ M. Kent Jennings, "Political Participation in the Chinese Countryside," American Political Science Review, Vol. 91 (2), June 1997, pp. 361-372; Feng Chen, pp. 449-52.

${ }^{57}$ Feng Chen, pp. 452-3.

58 Ibid., pp. 453-56.

${ }^{59} \mathrm{Ibid}$., pp. 462-463.
} 
by the world's paramount centers of capitalism to consolidate neoliberalism.

The notion of "Third Thought Emancipation" has been advanced by Li Junru, who has served as the deputy director of the Central Propaganda Department. An ideological breakthrough has been achieved, in this tack. Theory is freed from the issue of public versus private ownership, it is claimed, and so this allows the reform (privatization) of the SOEs. ${ }^{60}$

Two economists, who were top advisors to the Government, Dong Funai and Gao Shangquan, attempted to counter the left by arguing that the market, as such, has no political attributes, but is "neutral," having the ability to serve either socialism or capitalism. Dong argued that "ownership was not a criterion to distinguish socialism from capitalism." The distinguishing factor was "the extent to which equity and efficiency were combined." While the Third Thought Thesis was not officially endorsed by the Party, official ideologues have not offered persuasive criticism of the arguments from the left. These feeble attempts to lay an ideological basis for de facto capitalism reveal the ideological problems faced by the Communist Party, as well as its intellectual bankruptcy. Political opposition, on the other hand, is not tolerated. ${ }^{61}$ Karl Marx would have likely been amused by such shenanigans.

\section{Profile of Recent Development: Shanghai, Urbanization and Proletarianization}

It is clear that Shanghai is the main center of capitalist growth, in China, second only to Hong Kong. Shanghai is an economic and manufacturing center that draws a floating population from rural areas with all the attractions and degradation that rapid development brings in such a metropolis. In the Maoist days, the economic and financial expertise of Shanghai was drawn on as people were sent out

\footnotetext{
${ }^{60}$ Ibid.

${ }^{61}$ Feng Chen, pp. 463; Acharya, p. 2908; Li Cheng, pp. 119-120.
} 
to help develop the countryside. ${ }^{62}$ Shanghai also demonstrates the emerging disparity between the booming coastal regions and western provinces. ${ }^{63}$ Capital has fled from the west of China to the eastern regions. While major problems emerge from privatization, from the US perspective, economic liberalization is not fast enough. ${ }^{64}$ In Shanghai "All the power and opulence of the corporate world is clearly visible- globalization is not just something to discuss, it appears to be a well entrenched reality." 65

Even before reforms began seriously in 1992, Shanghai was the cash cow for the government, providing almost a quarter of central government revenue, while the city has only about one percent of the population. Shanghai has several features that give it the potential to be China's economic powerhouse: several key industries; a prime location, with access to the north and south coast and the Yangtze River Valley; developed human resources in science and technology; economic expertise; financial facilities; management expertise; and quality workers. These factors have led the government to promote Shanghai as the prime center of development after $1990 .{ }^{66}$ Former Premier Zhu Rongji was the former mayor of Shanghai.

Emerging policies to encourage economic growth have included tax holidays, free trade zones, promotion of service industries, and guarantee of land use for 50 to 70 years. In addition, Shanghai has been given more authority to make decisions on investment approval. A stock exchange is flourishing. Foreign department stores and supermarkets sprang up brought in along with foreign banks, finance and insurance companies. All these indicate the wider opening to outside capitalism. Business taxes were lowered

${ }^{62}$ J. Bruce Jacobs, "Shanghai: An Alternative Centre?" in Goodman, (ed), China's Provinces, pp. 163-93.

${ }^{63}$ Haishun Sun and Dilip Dutta, "China's economic growth during 1984-93: a case of regional dualism," Third World Quarterly, Vol. 18 (5), 1997, pp. 843-64.

${ }^{64}$ Nicholas R. Lardy, "China and the Asian Contagion," Foreign Affairs, Vol. 77 (4), July/Aug. 1998, pp. 78-88; Xiaobo Hu, pp. 641-57.

${ }^{65}$ Acharya, p. 4185.

66Jacobs, pp. 170, 179. 
to 33 percent to increase capital available for investment. This also gave more fiscal income to the city.

In 1992-3, growth rates were running at 14.9 percent in Shanghai. New policies were issued in 1995 to allow foreign trade companies to operate and joint venture companies were brought in along with foreign banks. The Pudong export processing zone (EPZ) was given special policies to allow it to catch up with other special economic zones (SEZs) and develop the Yangtze Valley. While the service sector is emerging, industry remains the basis of growth. The six pillars of industry are autos, iron, steel, petrochemical, power, telecommunications, and household electrical goods, with pharmaceuticals prominent. ${ }^{67}$

The result of these reforms has been mixed with both positive and negative social consequences. One sees better transport and housing, inflation, high cost of living, inequality of incomes, unemployment, a registered and a transient (floating) population, and a smaller group of new rich with access to new consumer products. There is a new transportation infrastructure, beltway, and underground and a second international airport. The housing in Shanghai is being privatized under cooperative schemes and a "public accumulation fund," but it is difficult for most to buy a residence. Once privately owned, the housing can go onto the market. There is a burgeoning real estate market; all this will most certainly lead to much greater inequality in future. ${ }^{68}$

The efficiency of state enterprises has increased but industrial restructuring has led to unemployment, with many of the old skills no longer needed. An unemployment scheme is being set up but the stipend is not really enough to live on and this payment is not available to both husband and wife at the same time in one family. Payments can go on for up to three years but after that the employee is dismissed. The influx of outsiders has also led to increasing crime. In 1993, there were some 3 million transient population in Shanghai.

${ }^{67}$ Ibid., pp. 172-73.

${ }^{68}$ Ibid., pp. 176-77. 
In the city the birth rate has declined with the permanent population trend toward aging. ${ }^{69}$

A survey of the immigrants to Shanghai shows that most are from nearby provinces and are relatively young; some 64 percent are male. Eighty percent reside in the urban area of the province. Most are from rural China and only 13 percent stay for more than 3 years. Nine percent of immigrants are illiterate, 10 percent have secondary education, and 26 percent have completed primary education. About 75 percent come to the city for economic reasons. The transients are found working mostly in construction and labor. More than a half million are de facto permanent residents but lacking an official "blue card" or permit to live in the city. ${ }^{70}$ These immigrants are at a further disadvantage since many jobs are reserved for official, permanent residents.

As in other emerging cities across the world, a new rich class is emerging. The new rich are generally stock market traders, private business bosses, the self employed, entertainment stars, taxi drivers, managers in foreign funded firms, experts, technicians, and bankers.

Politically, the city tends to leave politics to Beijing. There is a favorable relationship between the two cities. Both former President Jaing Zemin and former Premier Zhu Rongji were former mayors of Shanghai, so that some have spoken of a "Shanghai Gang" in Beijing. The city is seen to be well managed and efficient with an effective housing policy, so that the leaders have high national legitimacy. Shanghai has a big city image that is disliked by the rest of China. ${ }^{71}$

High tech conglomerates like Konka TV that are backed by the state in order to enable them to develop a viable niche in the market, in the pattern followed in other East Asian countries such as Japan, Taiwan, and South Korea, are increasingly being set up to capture a larger share of the global market. China has used its skills to learn to compete in the global market place even beating out countries such as India with very low wages.

\footnotetext{
${ }^{69}$ Ibid., pp. 179-80.

${ }^{70}$ Ibid., pp. $180-83$.

${ }^{71}$ Ibid., pp. $185-88$.
} 


\section{China in the Global Economy}

China was able to insulate itself from the Asian financial crisis in 1998 through its macroeconomic stabilization policies. These included substantial foreign exchange reserves, huge current and capital account surpluses, a high ratio of foreign direct investment, to short term capital inflows, and inconvertibility of the yuan on capital account. However, China's economy is becoming increasingly linked to the global political economy.

Former Premier Zhu Rongji delivered the government's most recent five year plan at the National People's Congress held in March 2001. It envisions 7 percent annual economic growth until 2005, a rise in China's GDP by one-third to $\$ 1.5$ trillion, and a massive increase in Foreign (FDI) continuing strong exports. China is presently running a trade surplus with exports of $\$ 249$ billion and imports of $\$ 225$ billion a year The US imported over $\$ 100$ billion from China and Japan some $\$ 40$ billion a year. China entered the World Trade Organization in 2001.

Recent indicators of China's emergence as a major capitalist power include the listing of at least three firms on Wall Street with 30 to 50 more in the pipeline. Some 12 billion dollars was raised on Wall Street with the other firms targeted to raise 25 to 30 billion. A record $\$ 8$ billion of foreign investment flowed into China in June 2004.

In spite of this massive capital inflow, there are an estimated 150 to 200 million unemployed or underemployed. Companies are constantly restructured or shut down. Lack of demand has emerged as people are forced to spend more for pensions, medical care and children's education. The budget deficit has reached $\$ 30$ billion . But the massive restructuring of the economy goes forward with the closing down of more state owned industries. Some 1000 large to medium state owned industries have been forced into bankruptcy since 1998. Some 20 to 30 of these industries employed over 10,000 staff. Benxi mining with 54,000 workers was shut down. Some 14 million were laid off in 1999 and 2000 and another 7 million in 2001. Asset Management companies (AMC's) are currently restructuring state firms which have unpaid debts of some $\$ 160$ billion to China's four state banks, selling them to local or overseas entrepreneurs. 
There has been a "transformation of large sections of the Communist Party bureaucracy and political elite into a new, property-owning class." Businessmen now make up about half the membership of Communist Party branches in Shanghai. And 12 of the 50 richest individuals in China were among the delegates at the National People's Congress (NPC).

Wholly state-owned companies are now only 28.7 percent of firms, down from 47 percent in 1996. The percent of shareholding firms has increased from 5 percent to 21.4 percent in the same period. Privately-owned and foreign firms are now over 50 percent of Chinese firms. The rampant speculation on the Shanghai stock market has pushed capitalization of China's stock markets to over \$581 billion. Members of the NPC standing committee have earned at least 12 million dollars from trading stocks.

But rising inequality means that 20 percent of the population earn 42.4 percent of income, own 42.5 percent of all wealth and control 80 percent of bank savings deposits. Some 106 million people survive on less than one dollar day according to the World Bank. If this is not capitalism, then it would certainly be difficult to tell the difference.

\section{Conclusion: Neoliberalism and Imperialism on a Global Scale}

The Maoist period which engaged in large-scale rural development laid the basis for a quantum leap forward in production and consumption under Deng Xiaoping. It has been noted that the pattern of development in China resembled other East Asian states, such as Taiwan and South Korea. ${ }^{72}$ Deng Xiaoping has used neoliberal policies under political authoritarianism to insert China into the contemporary global economy. ${ }^{73}$

\footnotetext{
${ }^{72}$ Grabowski, pp. 24-25.

${ }^{73}$ John J. Quinn, "Economic Accountability: Are Constraints in Economic Decision Making a Blessing or a Curse," Scandinavian Journal of Development Alternatives and Area Studies, Vol. 19 (4), December 2000, pp. 131-169.
} 
Today, "Socialism with Chinese characteristics" is actually neoliberalism with Chinese characteristics. An emerging entrepreneurial bourgeoisie and liberal middle class intellectuals are demanding greater space in civil society, while on the left, and industrial proletariat with working class consciousness is being forged. The Government fears any kind of political opening, and is at pains to defend its policies as "Marxist" and "socialist." Obsequious Chinese state officials wish to crush the genuine left political movement which is using as its tool the ideology the government facetiously claims as its own.

Chinese development, in fact, is part and parcel of the neoliberal capitalist development all across the developing world. China, since the Revolution in 1948, has emerged from a country engaged in primitive "socialist" accumulation under Mao to accumulation under the current global wave of neoliberalism orchestrated by the IMF and World Bank. Both, at root, are forms of capitalist accumulation. As China looms larger on the world stage of capitalist production, the question arises as to whether the Chinese brand of capitalism will produce a Chinese industrial proletariat to challenge its exploitation. Indeed, whether the emerging Chinese proletariat will join hands with a global working class to oppose neoliberalism and its offspring, the American military imperialism it underpins, is the larger historical question. 